\title{
Let-7b and microRNA-199a inhibit the proliferation of B16F10 melanoma cells
}

\author{
DAN XU ${ }^{1}$, JIANXIANG TAN ${ }^{1}$, MING ZHOU $^{2}$, BIMEI JIANG ${ }^{3}$, HUIQING XIE $^{1}$, \\ XINMIN NIE ${ }^{1}$, KUN XIA ${ }^{4}$ and JIANDA ZHOU ${ }^{1}$ \\ ${ }^{1}$ Department of Plastic Surgery, The Third XiangYa Hospital of Central South University; \\ ${ }^{2}$ Department of Cancer Research, Xiang Ya School of Medicine; ${ }^{3}$ Department of Pathophysiology, Xiang Ya School \\ of Medicine; ${ }^{4}$ Chinese State Key Laboratory of Medical Genetics, Changsha, Hunan 410013, P.R. China
}

Received May 15, 2012; Accepted August 13, 2012

DOI: $10.3892 / \mathrm{ol} .2012 .878$

\begin{abstract}
Cutaneous melanoma is an aggressive form of human skin cancer characterized by high metastatic potential and poor prognosis. Biomarkers of metastatic risk are critically needed to instigate new auxiliary measures in high-risk patients. In clinical specimens of skin melanoma, we previously found that let-7b, microRNA-199a and microRNA-33 were significantly associated with metastatic melanoma, and thus may be the key to melanoma treatment. In this study, we examined the effect of overexpression and inhibition of let-7b and microRNA-199a. Plasmids overexpressing these genes were transfected into B16F10 melanoma cells, and let-7b and microRNA-199a expression were evaluated at the RNA, protein and cellular level. Cyclin D1 expression was significantly higher in cells transfected with let-7b plasmid and let-7b inhibitor compared with control cells $(\mathrm{P}<0.05)$. In turn, Met expression in the microRNA-199a plasmid group and microRNA-199a inhibitor group was significantly higher than in the control group $(\mathrm{P}<0.05)$. The proliferation rate of B16F10 cells transfected with let-7b or microRNA-199a was lower than that of the control group, particularly until the third day after transfection when the proliferation rate dropped to the lowest value $(\mathrm{P}<0.05)$. In addition, the apoptosis rates of the let-7b plasmid group and microRNA-199a plasmid group were significantly higher compared to that of the control group $(\mathrm{P}<0.05)$. These results suggest that let-7b and microRNA-199a may be negative regulators of B16F10 cell proliferation.
\end{abstract}

Correspondence to: Professor Jianda Zhou, Department of Plastic Surgery, The Third XiangYa Hospital of Central South University, Tong Zi Po Road, Changsha, Hunan 410013, P.R. China E-mail: zjianda@yahoo.com.cn

Key words: microRNA, let-7b, microRNA-199a, melanoma, Met, cyclin D1, cell proliferation

\section{Introduction}

Melanoma, a malignancy that arises from melanocytes, accounts for approximately $10 \%$ of skin tumors. It has hereditary aspects (1), and in recent years its incidence has increased (2). The early symptoms are often difficult to detect, thus making treatment more challenging since the disease progresses rapidly and undergoes metastasis to result in poor prognosis. Clinical diagnosis is most frequently made once the cancer has undergone distant metastasis or regional lymph node metastasis. The mortality rate currently stands at $80 \%$, while the 5 -year survival rate is less than $5 \%$ and is significantly correlated with the number of metastases (3). Therefore, the interpretation of melanoma invasion and metastasis mechanisms to control tumor development is the key to lowering mortality.

microRNAs are small, non-coding RNAs that regulate gene expression by binding to mRNA 3'UTRs, which results in mRNA degradation or translation (4-8). microRNA regulates embryonic development, cell proliferation, apoptosis, cell differentiation, lipid metabolism and other important cellular functions, particularly in tumor development, where its function is similar to that of oncogenes or tumor suppressor genes (9-11). When oncogenes and tumor suppressor genes are disrupted, or the activity of telomerase persists, tumorigenesis occurs. The most notable feature of tumor cells is uncontrolled proliferation and non-differentiation. There are three checkpoints in the cell cycle, which control $G_{0} / G_{1}, G_{1} / S$ and $G_{2} / M$. By regulating the cell cycle, it is possible to inhibit tumor growth and proliferation.

In clinical specimens of skin melanoma, we previously found that let-7b, microRNA-199a and microRNA-33 were significantly associated with metastatic melanoma(12). Notably, opposing findings have been described for ovarian carcinoma (13) and non-small cell lung cancer (14). Downregulated expression of let-7b and microRNA-199a was significantly correlated with poor prognosis in ovarian carcinoma (13). In this study, B16F10 melanoma cells were transfected with plasmids that targeted let-7b and microRNA-199a, in order to investigate the correlation between microRNA expression and melanoma metastasis. 


\section{Materials and methods}

The study was approved by the The Third XiangYa Hospital of Central South University, Hunan, China.

Materials. PGCsi-U6/neo/GFP-hsa-let-7b plasmid and PGCsi-U6/neo/GFP-hsa-miR-199a plasmid were obtained from Ji Kai Chemical Technology Company (Shanghai, China). Hsa-let-7b miRNA inhibitor, hsa-microRNA-199a miRNA inhibitor and microRNA-Ribo ${ }^{\mathrm{TM}}$ Inhibitor Negative Control were purchased from Rui Bo Biological Technology Company (Guangzhou, China).

Grouping. Experiments were divided into the following groups: i) control group: B16F10 cells; ii) let-7b plasmid group: liposome-mediated targeting of let-7b overexpression plasmid; iii) microRNA-199a plasmid group: liposome-mediated targeting of microRNA-199a overexpression plasmid; iv) empty plasmid group: liposome-mediated targeting of empty plasmid; v) let-7b microRNA inhibitor group: liposome-mediated targeting of let-7b inhibitor fragment; vi) microRNA-199a inhibitor group: liposome-mediated targeting of microRNA-199a inhibitor fragment; vii) inhibitor control group: liposome-mediated targeting of negative control inhibitor fragment.

Transfection. B16F10 cells were seeded at a density of $5 \times 10^{4}$ cells $/ \mathrm{ml}$ in 6 -well plates. Each well contained $2 \mathrm{ml}$ RPMI-1640 complete medium. When cells had reached $80-90 \%$ confluency, plasmids were transfected, while inhibitor fragments were transfected into cells at 30-50\% confluency. Cells were washed twice with PBS, and $1.5 \mathrm{ml}$ serum-free RPMI-1640 medium was added to each well. Then $4.0 \mu \mathrm{g}$ plasmid DNA or $5.0 \mu 1$ inhibitor was added to $250 \mu 1$ serum-free RPMI-1640 medium (liquid A), and $8 \mu 1$ or $5 \mu 1$ liposomes were added to $250 \mu 1$ serum-free RPMI-1640 medium (liquid B). Then, liquids $\mathrm{A}$ and $\mathrm{B}$ were mixed, incubated for $15 \mathrm{~min}$ at room temperature, and added to 6-well plates at $500 \mu \mathrm{l} / \mathrm{well}$. Approximately 4-6 h after transfection, RPMI-1640 complete medium was replaced.

Real-time PCR verification of let-7b and microRNA-199a expression. Cells were collected at 24-36 h after transfection and lysed using TRIzol solution to extract RNA. Following quantitation using an ultraviolet spectrophotometer, $1 \mu \mathrm{g}$ genomic RNA was incubated in $12 \mu \mathrm{l}$ buffer solution at $70^{\circ} \mathrm{C}$ for $10 \mathrm{~min}$. The reaction protocol was performed according to the manufacturer's instructions (reverse transcription kit, K1662, Fermentas, Canada), and DNA was amplified by PCR. Reactions consisted of the following constituents: RNA $(1 \mu \mathrm{g})$, $62.5 \mathrm{nM}$ RT primer mix $(1 \mu \mathrm{l})$, DEPC water (added to make the total volume to $20 \mu \mathrm{l}), 5 \mathrm{X}$ reaction buffer $(4 \mu \mathrm{l}), 20 \mu \mathrm{g} / \mu \mathrm{l}$ RNase inhibitor $(1 \mu \mathrm{l}), 10 \mathrm{mM}$ dNTP mix $(2 \mu \mathrm{l})$ and M-MuLv $(1 \mu \mathrm{l})$, totaling $20 \mu \mathrm{l}$ reaction volume. Reaction conditions consisted of $42^{\circ} \mathrm{C}$ for $60 \mathrm{~min}$, then $70^{\circ} \mathrm{C}$ for $5 \mathrm{~min}$. Following reverse transcription, reactions were prepared according to SYBR Premix Ex Taq ${ }^{\mathrm{TM}}$ (DRRO41A, Takara, Japan) instructions. The following reaction constituents were used: cDNA $(2 \mu \mathrm{l})$, SYBR $(10 \mu \mathrm{l}), 10 \mu \mathrm{M}$ forward primer $(0.4 \mu \mathrm{l}), 10 \mu \mathrm{M}$ reverse primer $(0.4 \mu \mathrm{l}), 50 \mathrm{X} \operatorname{ROX}(0.4 \mu \mathrm{l}), \mathrm{ddH}_{2} \mathrm{O}(6.8 \mu \mathrm{l})$, totaling $20 \mu \mathrm{l}$. Reaction conditions were as follows: $95^{\circ} \mathrm{C}$ for $10 \mathrm{sec}$, then $95^{\circ} \mathrm{C}$ for $5 \mathrm{sec}, 60^{\circ} \mathrm{C}$ for $30 \mathrm{sec}, 95^{\circ} \mathrm{C}$ for $15 \mathrm{sec}$, $60^{\circ} \mathrm{C}$ for $15 \mathrm{sec}$ and $95^{\circ} \mathrm{C}$ for $15 \mathrm{sec}$ for a total of 40 cycles. Based on the results obtained, the relative expression value $\mathrm{F}=2-\Delta \Delta \mathrm{ct}$ was calculated $(\Delta \mathrm{ct} 1=$ sample group average target gene ct value - average internal reference gene value; $\Delta$ ct $2=$ control group average target gene ct value - average internal reference gene value; $\left.\Delta \Delta \mathrm{ct}=\Delta \mathrm{ct}_{1}-\Delta \mathrm{ct}_{2}\right)$.

Western blot verification of cyclin D1 and Met expression. Cells were harvested $72 \mathrm{~h}$ after transfection then lysed with sodium dodecyl sulfate loading buffer solution. The protein concentration of each sample was determined using the Bradford method. Thirty micrograms of protein supernatant was subjected to sodium dodecyl sulfate-polyacrylamide gel electrophoresis and transferred onto nitrocellulose membranes. Membranes were blocked for $1.5 \mathrm{~h}$ and incubated with mouse anti-cyclin D1 antibody $(1: 1,000)$, mouse anti-Met antibody $(1: 1,000)$, or mouse anti- $\alpha$-tubulin antibody $(1: 10,000)$. All membranes were incubated at $4^{\circ} \mathrm{C}$ overnight. Membranes were washed three times with PBST then incubated for $1 \mathrm{~h}$ at room temperature in anti-mouse secondary antibody $(1: 10,000)$. ECL chemiluminescence was used to reveal proteins, and Bandscan software (Glyko, Novato, CA, USA) was used to scan the gray value of western blot bands to calculate the relative content of protein as follows: protein relative content $=$ gray value of protein bands/gray value of $\alpha$-tubulin bands.

MTT mapping cell growth curve. 96-well plates were inoculated with 10,000 B16F10 cells per well. After $24 \mathrm{~h}$, cells were transfected with plasmids (five wells per group). MTT assays were performed 1 to 5 days after transfection as follows: $20 \mu \mathrm{l}$ MTT solution was added to each well and cells were incubated for $4 \mathrm{~h}$, then the supernatant was carefully discarded to terminate the reaction. Next, $150 \mu \mathrm{l}$ DMSO was added to each well, and samples were oscillated for 10 min to fully dissolve any crystals. Absorption was measured at $490 \mathrm{~nm}$.

Apoptotic rate detected by flow cytometry. Cells were harvested $24 \mathrm{~h}$ after transfection, then centrifuged at $800 \mathrm{rpm}$ for $5 \mathrm{~min}$ and supernatant was removed. The cell suspension was then fixed in pre-cooled $10 \%(\mathrm{v} / \mathrm{v})$ ethanol at $4^{\circ} \mathrm{C}$ for $24 \mathrm{~h}$. The cell density was adjusted to 10,000 cells $/ \mathrm{ml}$ and fixed cells were treated with propidium iodide staining solution for $30 \mathrm{~min}$ in the dark. Apoptosis was measured using a flow cytometer.

Statistical analysis. Data were analyzed with SPSS 13.0 (SPSS, Chicago, IL, USA). Experimental data were presented as means $\pm \mathrm{SD}$ and the paired t-test was used to show differences between each group. $\mathrm{P}<0.05$ was considered to indicate a statistically significant difference.

\section{Results}

Transfection of plasmids or inhibitors into B16F10 cells. At $24 \mathrm{~h}$ after transfection, B16F10 cells were examined by fluorescence microscopy to ensure successful uptake of plasmids or inhibitors. Green fluorescent cells were observed in the empty plasmid, let-7b plasmid and microRNA-199a plasmid groups (Fig. 1A and B), and red fluorescent cells were observed in 
A

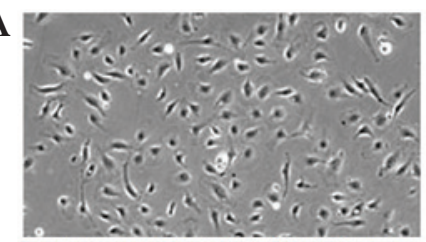

$\mathrm{C}$

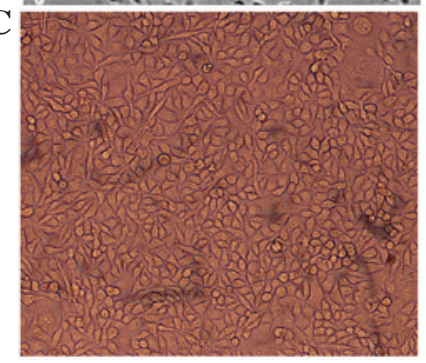

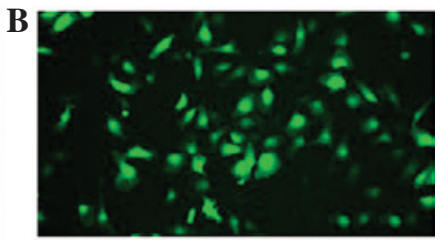

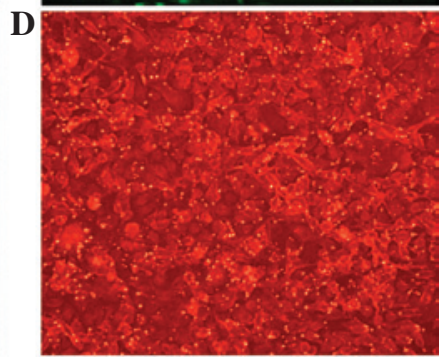

Figure 1. Plasmid groups and inhibitor groups of B16F10. (A) Plasmid group of B16F10 (visible light x100). (B) Plasmid group of B16F10 (fluorescence x100). (C) Inhibitor group of B16F10 (visible light x100). (D) Inhibitor group of B16F10 (fluorescence x100).

A

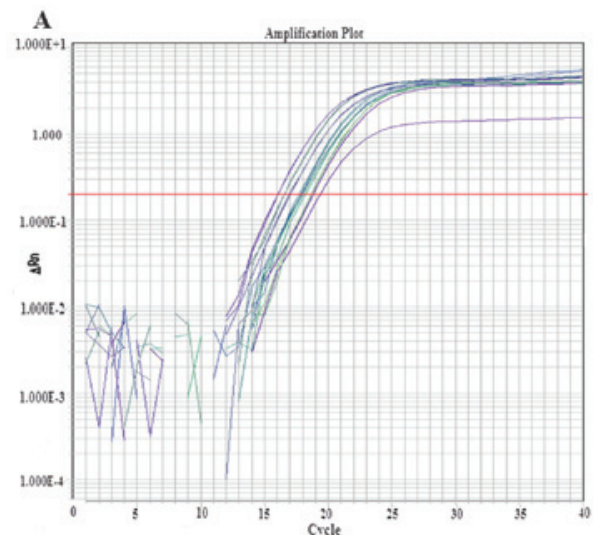

C

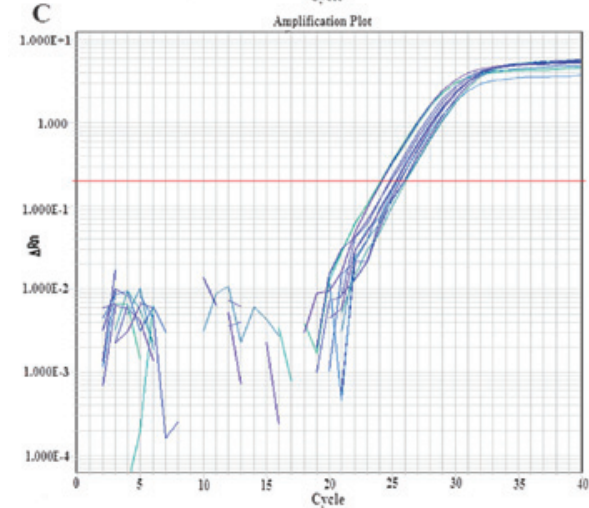

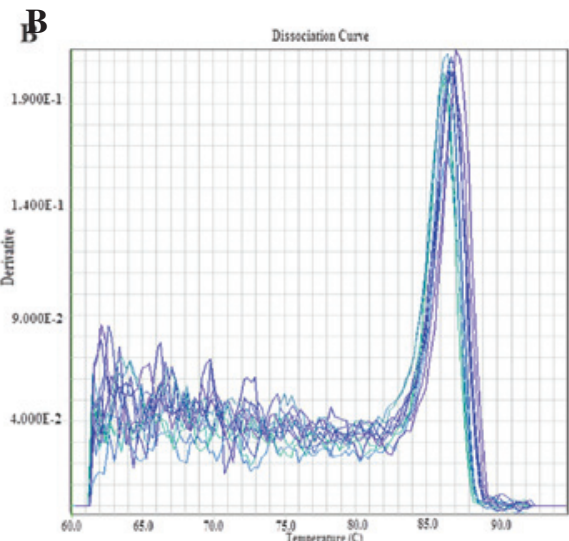

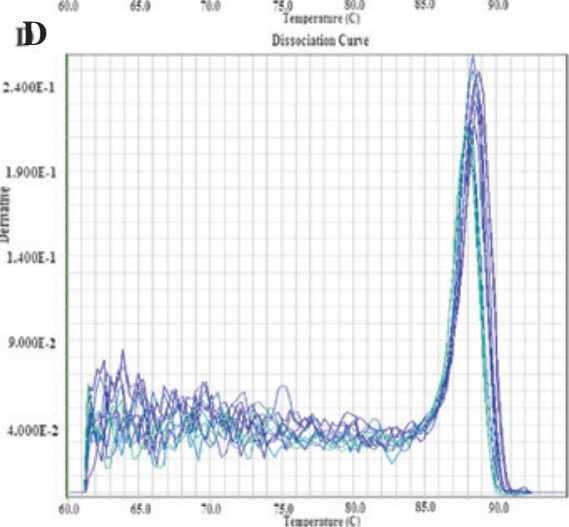

Figure 2. Let-7b and microRNA-199a real-time PCR. (A) Amplification curve of let-7b. (B) Dissolution curve of let-7b. (C) Amplification curve of microRNA-199a. (D) Dissolution curve of microRNA-199a.

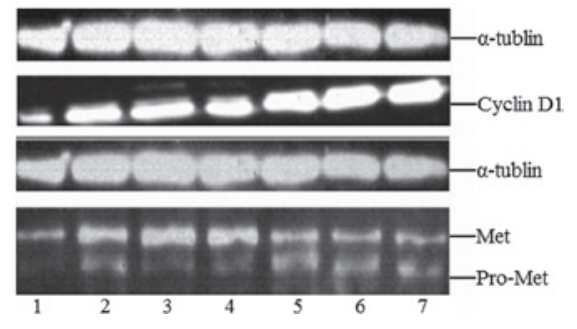

Figure 3. Expression of cyclin D1 and Met (1, control group; 2, empty plasmid group; 3, let-7b plasmid group; 4, microRNA-199a plasmid group; 5, inhibitor control group; 6, let-7b inhibitor group; 7, microRNA-199a inhibitor group). the let-7b inhibitor, microRNA-199a inhibitor and inhibitor control groups (Fig. 1C and D). In turn, no green fluorescent cells were observed in the control group. Plasmids were tagged with green fluorescent protein (GFP), and inhibitor fragments were labeled with cyanine (Cy) 3 .

Real-time PCR verification of let-7b and microRNA-199a gene expression

Let-7b gene expression. Compared with the control group, the relative gene expression of the let-7b plasmid group 
$\mathbf{A}$

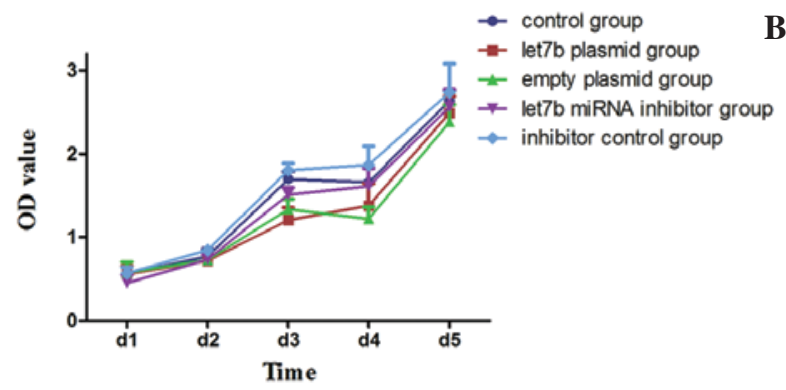

B

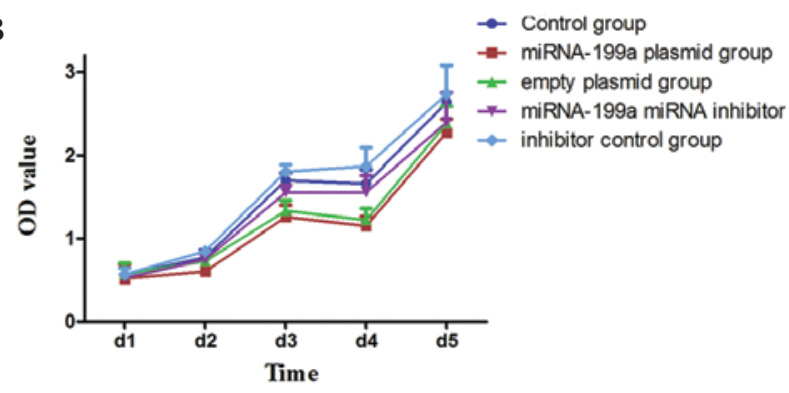

Figure 4. Effect of let-7b and microRNA-199a on B16F10 cell proliferation.
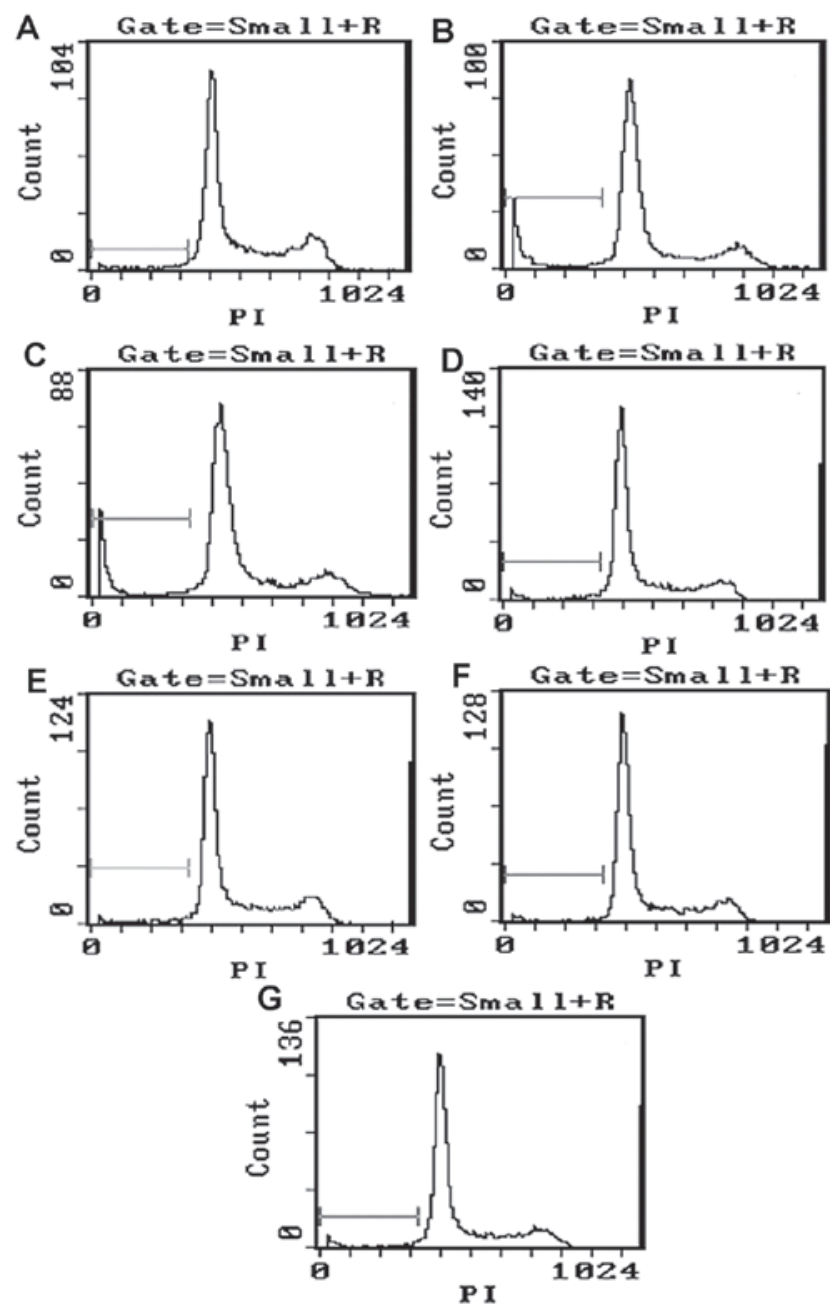

Figure 5. Apoptosis rate. (A) Control. (B) Let-7b plasmid. (C) microRNA-199a plasmid. (D) Empty plasmid. (E) Let-7b inhibitor. (F) microRNA-199a inhibitor. (G) Inhibitor control.

(3.8776 \pm 0.1372$)$ was significantly higher $(t=29.651, \mathrm{P}<0.05)$, and the relative expression of the let-7b inhibitor group $(0.2057 \pm 0.0263)$ was significantly lower $(t=42.704, \mathrm{P}<0.05)$. However, there were no significant differences between the empty plasmid group $(1.1400 \pm 0.2769)$ and the inhibitor control group $(0.9760 \pm 0.2300)(\mathrm{P}>0.05$; Fig. 2A and $\mathrm{B})$.

microRNA-199a gene expression. Compared with the control group, the relative expression of the microRNA-199a plasmid group $(2.8660 \pm 0.2821)$ was significantly higher $(\mathrm{t}=13.656$, $\mathrm{P}<0.05$ ), while the relative expression of the microRNA-199a inhibitor group $(0.2656 \pm 0.0253)$ was significantly lower $(\mathrm{t}=41.028, \mathrm{P}<0.05)$. However, there were no significant differences between the empty plasmid group $(0.9809 \pm 0.1703)$ and the inhibitor control group $(0.7512 \pm 0.0690)(\mathrm{P}>0.05$; Fig. 2C and D).

\section{Western-blot detection of cyclin DI and Met expression}

Cyclin D1 protein expression. Compared with the control group (0.997 \pm 0.041$)$, the relative expression of cyclin D1 in the let-7b plasmid group (2.023 \pm 0.315$)$, the microRNA-199a plasmid group (1.763 \pm 0.172$)$, the empty plasmid group (1.490 \pm 0.292$)$, the let-7b inhibitor group $(1.857 \pm 0.377)$, the microRNA-199a inhibitor group $(1.590 \pm 0.286)$ and the inhibitor control group $(1.443 \pm 0.099)$ was higher. However, in the let-7b plasmid and let-7b inhibitor groups the relative expression of cyclin D1 was significantly increased ( $\mathrm{t} \geq 13.733$, $\mathrm{P}<0.05)$, and between other groups there were no significant differences ( $\mathrm{P}>0.05$; Fig. 3).

Met protein expression. Compared with the control group (2.2 \pm 0.198$)$, the expression of Met in the let-7b plasmid group (3.24 \pm 0.340$)$, the microRNA-199a plasmid group $(5.19 \pm 0.309)$, the empty plasmid group (2.85 \pm 0.047$)$, the let-7b inhibitor group (2.49 \pm 0.068$)$, the microRNA-199a inhibitor group (4.87 \pm 0.044$)$ and the inhibitor control group $(2.73 \pm 0.033)$ was higher. However, in the microRNA-199a plasmid and microRNA-199a inhibitor groups the relative expression of Met was significantly increased $(\mathrm{t} \geq 17.905, \mathrm{P}<0.05)$, and between other groups, there were no statistically significant differences ( $\mathrm{P}>0.05$; Fig. 3).

Cell proliferation rate. $\mathrm{B} 16 \mathrm{~F} 10$ cells were treated with the different plasmids or inhibitors, and 1-5 days after transfection absorption values were measured, as described in Materials and methods (Fig. 4).

Compared with the control group, the proliferation rate of B16F10 cells transfected with let-7b or microRNA-199a was lower, and on the third day after transfection, the rate reached the lowest value $(\mathrm{P}<0.05)$. The rate was not significantly different in the empty plasmid, let-7b inhibitor, microRNA-199a inhibitor and inhibitor control groups $(\mathrm{P}>0.05)$.

Apoptotic rate detected by flow cytometry. Compared with the control group $(5.77 \pm 1.74 \%)$, the apoptotic rate of the let- $7 \mathrm{~b}$ 
plasmid group $(11.8 \pm 1.19 \%)$ and the microRNA-199a plasmid group $(11.3 \pm 1.59 \%)$ was significantly higher $(\mathrm{t} \geq 36.867, \mathrm{P}<0.05)$. However, no significant differences were found in apoptotic rates between the empty plasmid group $(6.75 \pm 1.59 \%)$, the let-7b inhibitor group $(4.39 \pm 1.52 \%)$, the microRNA-199a inhibitor group $(4.97 \pm 1.47 \%)$, the inhibitor control group $(6.68 \pm 1.71 \%)$ and the control group ( $\mathrm{P}>0.05$; Fig. 5).

\section{Discussion}

Very little is known about microRNA expression patterns in melanoma. Our previous studies have shown that in metastatic skin melanoma 47 microRNAs showed a two-fold or greater reduction in expression, while 6 microRNAs exhibited a two-fold or greater increase in expression, including let-7b, microRNA-199a, microRNA-33, microRNA-193b, microRNA-22 and microRNA-222. Quantitative polymerase chain reaction (qPCR) of tumor samples revealed that let-7b, microRNA-199a, microRNA-33 and clinical transfer index (age, survival time, metastasis and death resulting from metastasis) are positively correlated (12). It has been reported that microRNA signatures differentiate melanoma subtypes; seven microRNAs (microRNA-142-3p, microRNA-486, microRNA-214, microRNA-218, microRNA-362, microRNA-650 and microRNA-31) significantly correlated with acral melanoma compared to non-acral melanoma (15). Furthermore, let-7b and microRNA-199a were upregulated in uveal (ocular) melanoma, showing highly significant associations with the high metastatic gene expression signature and loss of chromosome 3 , which have been shown to be more accurate predictors of metastasis than any clinical or pathological factors, and have served as surrogate endpoints for the identification of biomarkers in uveal melanoma (16-18). Similar findings have been found in both skin melanoma and uveal (ocular) melanoma, but it is unclear as to whether this finding is coincidental or whether it is an important indicator of metastasis.

Let-7b and microRNA-199a are involved in ovarian carcinogenesis and are associated with the prognosis of serous ovarian carcinoma; lower let-7b and microRNA-199a expression is correlated with worse prognosis (13). Let-7b is significantly downregulated in acute lymphoblastic leukemia compared with acute myeloid leukemia (19).

microRNA regulates the expression of genes at the posttranscriptional level, which can directly regulate oncogene and/ or tumor suppressor gene expression, and is also associated with the cyclin kinases to regulate the cell cycle. For example, let-7b negatively regulates the expression of Ras (20). In vitro overexpression of let-7b in melanoma cells downregulated the expression of cyclins D1, D3, A and cyclin-dependent kinase (Cdk) 4 (21). Let-7b overexpression leads to an increased fraction of cells in G2/M, direct downregulation of $\mathrm{Cdc} 34$, and stabilization of Wee-1 kinase in primary human fibroblasts (22). microRNAs may also desensitize stem cells to external signals, leading to cell cycle arrest in G1/S transition $(23,24)$.

In this study, we investigated the effect of let-7b and microRNA-199a overexpression and inhibition on a melanoma cell line. We found that the expression of let-7b and microRNA-199a unexpectedly contrasted with the corresponding protein expression, suggesting that other mech- anisms may be involved aside from microRNAs. microRNAs generally negatively control gene function; however, when an internal environmental factor changes they may switch to positively regulating gene function. Our study suggests that inhibitors of let-7b and microRNA-199a genes caused these microRNAs to perform opposing functions in melanoma cells. microRNAs can act upon different target mRNAs. For example, let-7b controls CDC25A, CCND1, PLXND1, basigin expression (25), and also controls tumor suppressor genes such as RB1 and DLC1. In B16F10 cells, let-7b and microRNA-199a are expressed at different levels than in normal cells, and have different target genes, regulating cyclin D1 or acting as the inhibitory factor of Met protein deactivation to elevate the expression of cyclin D1 or Met protein. The genes regulating the expression of proteins are different, but these genes may act as a network so that when the intracellular equilibrium is altered to affect the expression of a signaling protein this affects the expression of another factor, and thus indirectly controls protein expression. microRNA-193b represses cell proliferation and regulates cyclin D1 in melanoma (26), while microRNA-34b, microRNA-34c and microRNA-199a have been shown to negatively regulate MET expression (27). Notably, microRNA-199a is downstream of ERK2 (28). While we have not determined the microRNA target genes in this study, our results demonstrate the existence of networks between microRNAs.

This study also explored the effect of let-7b and microRNA-199a at the cellular level using B16F10 cells. Overexpression of let-7b and microRNA-199a significantly decreased cell proliferation and increased apoptosis, suggesting that let-7b and microRNA-199a may be negative regulators of B16F10 cells.

microRNAs are of high interest in cancer research but are difficult to investigate (29). In this study, we investigated the effect of let-7b and microRNA-199a on melanoma proliferation at the microRNA level, providing new scientific evidence and ideas for clinical diagnosis and treatment. However, the mechanism of microRNA regulation of mRNA and its clinical applicability requires further study.

\section{Acknowledgements}

This research was supported by the National Natural Science Foundation of China (nos. 81071645, 81171882 and 30672035), and the National Natural Science Foundation of Hunan Province (nos. 11JJ6085 and 10JJ3030). The authors thank the Chinese State Key Laboratory of Medical Genetics for providing the experiment technology and equipment support, and Xia Jiahui for experimental design advice and technical guidance.

\section{References}

1. Xu Y, Zhou J, Luo C, He Q, Nie X, Zhao Y, Pokharel P, Wang S and $\mathrm{Xu}$ D: Melanoma clinical characteristics in China. Acta Laser Biology Sinica 16: 792-794, 2007.

2. Rigel DS: Trends in dermatology: melanoma incidence. Arch Dermatol 146: 318, 2010.

3. Schwartz B, Shoseyov O, Melnikova VO, McCarty M, Leslie M, Roiz L, Smirnoff P, Hu GF, Lev D and Bar-Eli M: ACTIBIND, a T2 RNase, competes with angiogenin and inhibits human melanoma growth, angiogenesis, and metastasis. Cancer Res 67: 5258-5266, 2007. 
4. He L and Hannon GJ: MicroRNAs: small RNAs with a big role in gene regulation. Nat Rev Genet 5: 522-531, 2004.

5. Shyu AB, Wilkinson MF and van Hoof A: Messenger RNA regulation: to translate or to degrade. EMBO J 27: 471-481, 2008

6. Neely LA, Patel S, Garver J, Gallo M, Hackett M, McLaughlin S, Nadel M, Harris J, Gullans S and Rooke J: A single-molecule method for the quantitation of microRNA gene expression. Nat Methods 3: 41-46, 2006.

7. Berezikov E, Cuppen E and Platerk RH: Approaches to microRNA discovery. Nat Genet 38: S2-S7, 2006.

8. Clancy JL, Nousch M, Humphreys DT, Westman BJ, Beiharz TH and Preiss T: Methods to analyze microRNA-mediated control of mRNA translation. Methods Enzymol 431: 83-111, 2007.

9. Hatfield S and Ruohola-Baker H: MicroRNA and stem cell function. Cell Tissue Res 331: 57- 66, 2008.

10. Giannakakis A, Coukos G, Hatzigeorgiou A, Sandaltzopoulos R and Zhang L: miRNA genetic alterations in human cancers. Expert Opin Biol Ther 7: 1375-1386, 2007.

11. Callis TE, Chen JF and Wang DZ: MicroRNAs in skeletal and cardiac muscle development. DNA Cell Biol 26: 219-225, 2007.

12. Zhou J, Tan J, Xie H, Wang Y, Li W and Zhong S: Primary cutaneous melanoma of microRNA gene chips. Journal of Chinese physician 13: 405-406, 2010.

13. Nam EJ, Yoon H, Kim SW, Kim H, Kim YT, Kim JH, Kim JW and Kim S: MicroRNA expression profiles in serous ovarian carcinoma. Clin Cancer Res 14: 2690-2695, 2008.

14. Heegaard NH, Schetter AJ, Welsh JA, Yoneda M, Bowman ED and Harris CC: Circulating microRNA expression profiles in early stage non-small cell lung cancer. Int J Cancer May 4. doi: 10.1002/ijc. 26153, 2011

15. Chan E, Patel R, Nallur S, Ratner E, Bacchiocchi A, Hoyt K, Szpakowski S, Godshalk S, Ariyan S, Sznol M, Halaban R, Krauthammer M, Tuck D, Slack FJ and Weidhaas JB: MicroRNA signatures differentiate melanoma subtypes. Cell Cycle 10: 1845-1852, 2011.

16. Worley LA, Onken MD, Person E, Robirds D, Branson J, Char DH, Perry A and Harbour JW: Transcriptomic versus chromosomal prognostic markers and clinical outcome in uveal melanoma. Clin Cancer Res 13: 1466-1471, 2007.

17. Onken MD, Worley LA, Person E, Char DH, Bowcock AM and Harbour JW: Loss of heterozygosity of chromosome 3 detected with single nucleotide polymorphisms is superior to monosomy 3 for predicting metastasis in uveal melanoma. Clin Cancer Res 13 2923-2927, 2007.

18. Worley LA, Long MD, Onken MD and Harbour JW: Micro-RNAs associated with metastasis in uveal melanoma identified by multiplexed microarray profiling. Melanoma Res 18: 184-190, 2008.
19. Mi S, Lu J, Sun M, Li Z, Zhang H, Neilly MB, Wang Y, Qian Z, Jin J, Zhang Y, Bohlander SK, Le Beau MM, Larson RA, Golub TR, Rowley JD and Chen J: MicroRNA expression signatures accurately discriminate acute lymphoblastic leukemia from acute myeloid leukemia. Proc Natl Acad Sci USA 104: 19971-19976, 2007.

20. Calin GA, Sevignani C, Dumitru CD, Hyslop T, Noch E, Yendamuri S, Shimizu M, Rattan S, Bullrich F, Negrini M and Croce CM: Human microRNA genes are frequently located at fragile sites and genomic regions involved in cancers. Proc Natl Acad Sci USA 101: 2999-3004, 2004.

21. Schultz J, Lorenz P, Gross G, Ibrahim S and Kunz M: MicroRNA let-7b targets important cell cycle molecules in malignant melanoma cells and interferes with anchorage-independent growth. Cell Res 18: 549-557, 2008.

22. Legesse-Miller A, Elemento O, Pfau S, Forman JJ, Tavazoie S and Coller HA: let-7 Overexpression leads to an increased fraction of cells in G2/M, direct down-regulation of Cdc34, and stabilization of Weel kinase in primary fibroblasts. J Biol Chem 284: 6605-6609, 2009.

23. Hatfield SD, Shcherbata HR, Fischer KA, Nakahara K, Carthew RW and Ruohola-Baker H: Stem cell division is regulated by the microRNA pathway. Nature 435: 974-978, 2005.

24. Karp X and Ambros V: Enhanced: encountering microRNAs in cell fate signaling. Science 310: 1288-1289, 2005

25. Fu TY, Chang CC, Lin CT, Lai CH, Peng SY, Ko YJ and Tang PC: Let-7b-mediated suppression of basigin expression and metastasis in mouse melanoma cells. Exp Cell Res 317: 445-451, 2011.

26. Chen J, Feilotter HE, Paré GC, Zhang X, Pemberton JG, Garady C, Lai D, Yang X and Tron VA: MicroRNA-193b represses cell proliferation and regulates cyclin D1 in melanoma. Am J Pathol 176: 2520-2529, 2010.

27. Migliore C, Petrelli A, Ghiso E, Corso S, Capparuccia L, Eramo A, Comoglio PM and Giordano S: MicroRNAs impair MET-mediated invasive growth. Cancer Res 68: 10128-10136, 2008.

28. Kim S, Lee UJ, Kim MN, Lee EJ, Kim JY, Lee MY, Choung S, Kim YJ and Choi YC: MicroRNA miR-199a* regulates the MET proto-oncogene and the downstream extracellular signal-regulated kinase 2 (ERK2). J Biol Chem 283: 18158-18166, 2008.

29. Osaki M, Takeshita F and Ochiya T: MicroRNAs as biomarkers and therapeutic drugs in human cancer. Biomarkers 13: 658-670, 2008. 